\title{
Synergy of policy implementation Through Corporate Social Responsibility in Gorontalo
}

\author{
Ismet Sulila \\ Universitas Negeri Gorontalo \\ Gorontalo, Indonesia \\ ismet.sulila@gmail.com
}

\begin{abstract}
This paper is study aimed to analize on synergy of policy implementation for the development of Small and Medium Enterprises (SMEs) through Corporate Social Responsibility program and strengthening the role of the government agencies in Gorontalo city was a contribution of higher education institution in meeting the current challenges among the community, especially related to the improvement of policy implementation on the development of SMEs. This was a qualitative study which was conducted for a year. The informants for this study were obtained through purposive sampling method, they were comprised of: SMEs groups as beneficiaries of CSR program, field facilitator of the CSR Program, Experts in Public Policy, NGOs, City Office of Cooperation, Industry and Trades, and other related government agencies. The data were collected through observation, interview, and documentation. The data analysis was started from data collection, data reduction, data presentation, and conclusion drawing. In addition, in each stage of the data collections, Focus Group Discussions (FGD) was held with all related stakeholders.
\end{abstract}

\section{Keywords : Synergy, Implementation, and Policy}

\section{INTRODUCTION}

The new paradigm of government has started since the enactment of Law No. 22 of 1999, which was later revised with Law No. 32 of 2004 has given the significant impact on both social and economic aspects. Development essentially means an effort to create welfare and just society, fulfillment of basic needs and the creation of welfare distribution for all components of society [1]. Within the context of regional autonomy, local government has authority and policy to manage its own region and potentials. One of the policies that need government's attention is the development of SMEs through corporate social responsibility program.The development of this sector needs to be considered because this sector can endure the economic crisis, this sector is also able to absorb workers and contribute toward the economic development. The basic concept of corporate social responsibility program on the other hand, is an on-going commitment from the business world to act ethically and contribute toward the development of local economy of the community where the company exists or for a wider community to improve their level of welfare. This basic concept encourages the development of SMEs in Gorontalo City, however, the reality is that the contribution of this sector is not yet significant. The observation showed that this sector is currently less developed due to the ineffectiveness of small and medium enterprises development. This situation needs the thoughtfulness of the stakeholders to actively participate through corporate social responsibility programs. Hence, this study was focused on the synergy and the strengthening of the local government agencies in Gorontalo City to develop the Small and Medium Enterprises through Corporate Social Responsibility.

\section{RESEARCH METHODOLOGY}

This study was a descriptive qualitative study with the following details

a. Data and Data Source

Data and data source in this study were: a) primary data. The primary data in this study were obtained from the informants through in-depth interview with key stakeholders, such as, the head of City Office of Cooperative, SMEs, Trades and Industry of Gorontalo City, Units that responsible for the implementation of CSR programs in each company, and SMEs group as beneficiaries of CSR programs. b) Secondary Source. The secondary source of data in this study was literatures relevant to the SMEs problem and CSR programs.

b. Data Collection Method

The data in this study were collected through several steps, namely: a) observation. This step was conducted to find the initial social condition of the object of study. In this sense, the initial state of the synergy and strengthening of the stakeholders' role in development of SMEs in GorontaloCity through CSR program. b) In-depth interview. This unstructured and in-depth interview was focused on the indicators of the study. c) Documentation. This step was to strengthen and enrich the data that were previously obtained through observation and in-depth interview, hence, it would assist the researcher in finding the answer of this problem. 


\section{Technique of Data Analysis}

Data were descriptively analyzed to obtain the description on the conditions of the synergy and role of stakeholders in development of SMEs through CSR program. In data analysis as Miles \&Hubberman, in Sugiono [2] described that data analysis in a qualitative research were processed from data interpretation through interactive model, where the data collection, data reduction, and data verification were a cycle that happen simultaneously and interact with one another.

\section{RESULTS AND DISCUSSION}

A. Research Findings

Development of companies and human activities rely on the availability of natural resources used as production stocks and as support for an ecosystem [3]. The significant contribution of SMEs' contribution in a region's economic development has made this sector as one of the main focus in it assistance and development. This showed that the informal sectors have subsidized many of the formal sector, in addition to these informal sector as efficient sector to supports the affordable livelihood [4]. This condition is also evident in Gorontalo City that implemented the assistance and development program of SMEs. The success of CSR programs relies on stakeholders that are directly involved in it, such as, government agencies, state owned companies and private companies, and SMEs group as beneficiaries of the program. This CSR programs have been implemented in observance with the prevailing laws and procedure. Regardless, the implementation of this CSR programs in SMEs sector is not significant yet. This condition urged the government as interested party in the development and assistance of SMEs to do the following things:

1) synergized the related stakeholders and institutions to make the assistance and development of SMEs through CSR effective, hence, it could achieve the target. Currently the City Office of Cooperative and SMEs of Gorontalo was an agency responsible for the development of SMEs including the development of SMEs through CSR programs. This agency was urged to actively participate in coordinating and synchronizing the SMEs development programs with other institutions such as, Regional Planning Agency, Office of Budget Management, Stateowned companies and private companies, as well as the Small and Medium Enterprises themselves. The fact showed that the implementation of CSR programs in development of SMEs was partially implemented that were evident in: a) the inexistence of mapping of SMEs based on the types to ease the assistance and development of these SMEs. b) the assistance and development programs of SMEs through CSR programs as part of the Cooperative and SMEs office was considered as additional workload for this institution. c) Lack of authority to coordinate and implement the efforts to assist and develop the SMEs through CSR Programs. d) The companies as parties responsible for disbursing the CSR program's budget tend to directly disburse the money to the SMEs without coordination with the related government agencies. e) lack of concern and openness of the participating SMEs, companies, and related agencies to obey the rules and regulation of CSR program. The synergy among the stakeholders becomes necessary. Through this, each stakeholders efforts to implement the assistance and development of SMEs through CSR programs would yield the expected result.

2) Strengthen the role and capacity of government agencies in implementing CSR programs, hence the target would be attained. On the other hand, the less optimization of companies in implementing CSR activities became one of the justifications for government to strengthen the implementation of CSR program for the development of SMEs. There were several indicators to measure the companies' willingness to implement the CSR program, such as: 1) not all the state-owned companies have Standard Operational Procedure for implementation of CSR, 2) not all companies have departments or units that specifically manage the CSR, 3) the state owned companies have not yet focused on preparing the human resources that readily equipped with capacity to manage the CSR program. These three aspects have led to unsustainable CSR program. CSR programs were considered as grants that are far from the expected result of sustainable responsibility. This condition could impact on the inefficiency of assistance and development program of SMEs through CSR program in Gorontalo City. Therefore, to maximize this program, a specific institution to coordinate all stakeholders in assisting and developing the SMEs through CSR program. This institution would independently and professionally work and would be directly responsible to the mayor in assistance and development of SMEs through CSR. This institution would be a representation of various stakeholders including the state-owned companies and private companies, as well as SMEs themselves. By giving this institution full authority to assist and develop SMEs through CSR, the development and assistance of SMEs through CSR would more focus, not only on the grant side but also in other management aspects. Therefore, this institution would create many realistic programs and it would also conduct evaluation for needed improvement in each terms.

\section{B. Discussion}

This study showed that the success of CSR program largely depended on the role of each related agencies. However, the related agencies also had their own tasks and functions. Here, it was obvious that the agencies are more focused on their main tasks and functions. Therefore, these additional tasks of implementing the CSR program had not yet obtained the needed attention. This study also showed that there is a need for synergy and strengthening the implementation of SMes development through CSR program. Based on this study, the efforts to assist and develop the SMEs in Gorontalo City were currently facing the following challenges: 
1. Synergy of assistance and development of SMEs

Small and Medium Enterprises (SMEs) development that does not synergize with other stakeholders turns out to give less effective result. It is shown by level of target achievement of micro, small and medium enterprises in Gorontalo City from time to time does not reach the set target yet. The findings show that this paradigm should be changed by synergizing and strengthening institutional of CSR program executor in Gorontalo City. It can be performed through the policy of municipal government to form a working unit of CSR program implementation. This working unit is assigned to coordinate all of the related agencies to play active role in the effort of micro, small and medium enterprises founding and development. It is needed since the related agencies do not get fully and actively involved toward founding effort. The founding effort seems to not go along with other agencies. Therefore, it is required a working unit that specifically deal with all of the agencies which are involved in CSR program implementation in Gorontalo City. By forming an integrated working unit, which is also a main focus, it is expected to create synergy among related agencies in SMEs development through CSR program.

2. Strengthening the role of local government agency.

Besides the needs on stakeholders' synergy, it is also needed strengthening active role of each working unit in small and medium enterprises development. Findings showed that working unit that involved in the efforts of direct assistance and development of micro, small and medium enterprises were still limited to only Department for Cooperatives, Small and Medium Enterprises. It was evident that the expected role of this department is big; meanwhile the number of SMEs that needs to be developed is in great quantities. This imbalance is one of the causes that make assistance programs by governmental agency toward SMEs were less effective. For that reason, another effort is needed, that is by involving all institutes on municipal government to play role on SMEs development. The method that can be done was by classifying SMEs based on the kinds of enterprise which then the assistance responsibility is given to each respected agency. Assistance was performed stage by stage by focusing on each problems faced by each enterprise group, either on management, financial, operational, production or marketing issues.

3. Model of synergy and strengthening the role of government in SMEs development through CSR program.

As an autonomous region, City of Gorontalo has some independences in the context of managing its own region [5]. On the basis of this authority, the synergy and strengthening the role of government agencies proposed as the output of this study was described as follow. This model proposed a professional unit that specifically cooperates with other institutions, including the state-owned companies to implement the managerial functions on the implementation of CSR in Gorontalo city. Theoretically, it has to be admitted that there is no single best model, all we have are selections of model that can be wisely chosen based on our needs [5]. The model is described in the following figure:

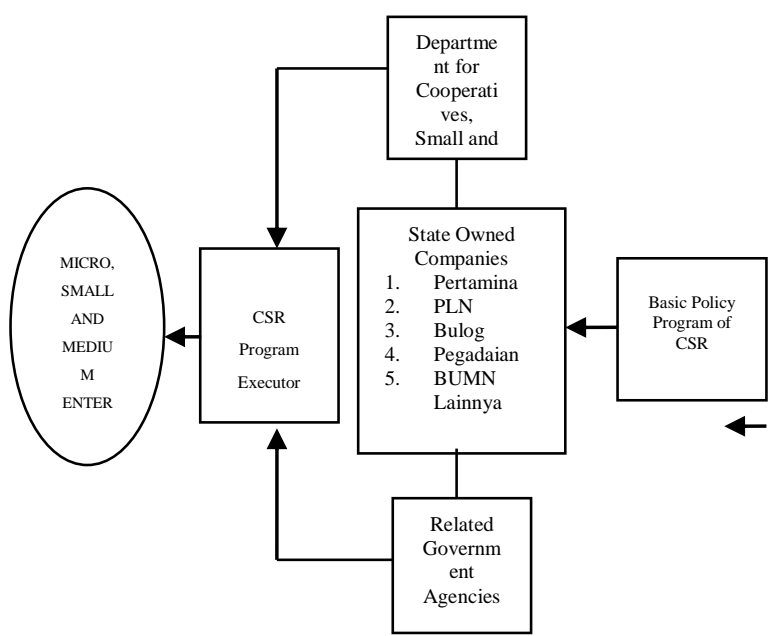

Figure 1. Model of Policy Implementation on the founding and development of micro, small and medium enterprises through CSR program in Gorontalo City

Based on the findings on the model of SMEs development through CSR program above, the working mechanism can be explained as follow: 1). CSR program basic policy is the laws and local regulation about CSR program for micro, small and medium enterprises development in Gorontalo City, 2). Department for Cooperatives, Small and Medium Enterprises, all of State-owned Enterprises and the CSR companies and related local government agency in Gorontalo City synergize to do preparation including preparing for budget allocation preparation on the number of micro, small and medium enterprises that are eligible and perform annual evaluation either internally or externally, and 3). Government of Gorontalo city established a unit of CSR program executor in which the members are representation of Department for Cooperatives, Small and Medium Enterprises, State-owned Enterprises and company, related local government agencies and micro, small and medium enterprises element, where this new unit is fully responsible on the effort of founding and development of micro, small and medium enterprises periodically.

\section{CONCLUSION}

A synergy among stakeholders in assistance and development of SMEs in Gorontalo city is needed. The strengthening of the role of the stakeholders is necessary to ensure the development of SMEs and its contribution toward the economic development of the city. This study on the model of synergy and the strengthening of the role of the stakeholders in assisting and developing the SMEs through CSR program is a comprehensive approach to be effectively used as an approach in developing the SMEs in Gorontalo city.

The importance of synergy requires the city government to take immediate actions to synergize all stakeholders in their effort to assist and develop the SMEs in Gorontalo City. Real commitment of the city government to strengthen the role of 
the stakeholders as well as authorizing them to actively participate in development of SMEs in this city is also needed. Applying the model in this study to synergize and strengthen the role of city government as a realization of commitment to assist and develop the SMEs through CSR program in Gorontalo City.

\section{REFERENCES}

[1] Naping, Hamka \& Musywirah Icha, 2016, Kelembagaan Lokal dan Modal Sosial Bagi Pengentasan Kemiskinan Pada Masyarakat Nelayan Pancana Kabupaten Barru Sulawesi Selatan, Proceeding Of International Conference On Multidiciplinary Reserarch (ICMR) 2016, Faculty of sosial and political science Hasanuddin University, Makassar, Indonesia

[2] Soegiono, 2007, Memahami Penelitian Kualitatif, Alfabeta, Bandung.

[3] Ludigdo, Dhanias, 2011, Tanggung jawab Sosial Perusahaan Bank Syari'ah, (Studi Kasus pada Bank Muamalat Indonesai Cabang Malang), Jurnal JAM, Volume 9, Nomor 4, Juli 2011.

[4] Kiayi, Burhanuddin \& Montotalu, 2015, Studi Peranan Sektor Informal Dalam Meningkatkan Pendapatan Keluarga Berpenghasilan Rendah di Kecamatan Tuminting Kota Manado, Jurnal Administrasi Publik, Volume IV, Number 035, October-December 2015.

[5] Kurnia, Gedeona, 2016, Implementasi Kebijakan Bantuan Operasional Kesehatan (BOK) di Puskesmas Pagarsih, Ibrahim Adjie dan Padasuka Kota Bandung,Jurnal STIA LAN Bandung, Volume XIII, Nomor 1, April 2014.

[6] Sulila, Ismet, 2015, A Reconstruction of Quality Assurance-Based Model of Academic Service Through The Implementation of Public Service Dimension at Faculty of Economic and Business, State University of Gorontalo, JurnalAdministrasi Negara STIA LAN Makassar, Volume 21 No2, Agustus 2015. 